\title{
Students' Digital Literacy Competence and English Study Habits
}

\author{
Sebastianus Menggo ${ }^{1}$, Hendrikus Midun ${ }^{2}$ and Pius Pandor ${ }^{3}$ \\ \{sebastian.pradana@gmail.com ${ }^{1}$, hendrik.m2002@gmail.com ${ }^{2}$, piuspandor@gmail.com ${ }^{3}$ \} \\ Universitas Katolik Indonesia Santu Paulus Ruteng, Indonesia ${ }^{12}$ Sekolah Tinggi Filsafat Widya \\ Sasana Malang, Indonesia ${ }^{3}$
}

\begin{abstract}
Digital literacy competence is an excellent choice as it promotes a more exciting and contextual instruction process. This research explores and reveals the students' profile of digital literacy competence and English learning habits. This study surveyed 402 students from Universitas Katolik Indonesia Santu Paulus Ruteng. A questionnaire was used to collect data, which was then quantitatively and qualitatively analyzed. According to the findings, students' digital literacy competence included in the medium category $(3,76)$. Three main digital competencies indicated this category; students' information literacy competence was in the medium category $(3,9)$, media was in the medium category $(3,6)$, and ICT competence was in the medium category $(3,78)$. English learning habits were also classified as high level, as shown by six learning habits: a review of the material, $77,61 \%$, self-evaluation, $92,29 \%$, summaries the material, $80,10 \%$, do exercises, $73,88 \%$, map priority, $88,56 \%$, and have a fixed schedule, $81,59 \%$.
\end{abstract}

Keywords: Digital literacy; English course; Teaching

\section{Introduction}

Undergraduates must be proficient in digital literacy. This idea is inspired by the argument that digital literacy skills have a wide range of implications in student life. Due to the apparent advancement of digital technology, every student is encouraged to continue to adapt to various learning interests, such as completing various college assignments, creating digital businesses, and maintaining or obtaining various job opportunities. Each individual must demonstrate adequate digital literacy competencies to support maximum work performance [1],[2]. The advancement and development of digital technology have consequences in many aspects of human life, including higher education. The availability of digital technology infrastructure is crucial for universities since it ensures the efficiency and success of all learning processes [3], [4].

The availability of digital technology infrastructure could facilitate the implementation of the learning process. The learning process is no longer reliant on fixed classroom sessions (faceto-face instruction). However, in dynamic classroom settings, classrooms focused on interactive media with extensive and stable internet access. Learning implementation based on digital technology availability will transform and provide new viewpoints on the ideal place of learning. On the other hand, university classrooms are no longer the primary learning centers for students since students can access a variety of learning sources without being limited by time and space. Educators are also not a complete learning resource since many digital learning resources can facilitate students to learn more optimally and meaningfully [5],[6]. 
Higher education learning processes are encouraged to take advantage of digital technology advancements to strengthen graduates with digital insight. Digital literacy competencies impact increasing learning achievement, initiative mindset, critical thinking, and learning autonomy. Digital-based learning becomes more engaging, interactive, varied, following the development of student learning styles and in line with the demands of today's advances in science and technology. Therefore, the advancement of digital technology is viewed as a stimulator for all stakeholders to adopt and uphold the spirit of student learning achievement. Digital-based learning can increase learning quality in terms of method, assessment, and output [11],[12]. These researchers added that digital-based learning is a space for knowledge transformation and a place for the creation of initiatives, creativities, changes in learning habits, and students' learning independence in supporting the achievement of expected learning targets.

The Indonesian government has affirmed the learning digitization through various digital media in learning activities, such as Video Conference, WebEx, Zoom, YouTube, Teacher Tube, Moodle, educational television programs, electronic books, and other website-based digital media [9]. The arguments underlying the use of these media are easy to access (easy and can be used by any student), cost-effectiveness and efficiency, interaction (creating two-way communication between lecturers and students, as well as students and students), flexible (can be used at anytime and anywhere), as well as novelty (digital technology always updates various application features as an attraction for its users) [14],[15].

This interpretation is the basis for the emergence of a digital-based learning paradigm. This paradigm is the best approach during the Covid-19 pandemic since it can reduce the rate of Coronavirus transmission while still keeping up with the demands of modern digital technology advances. The paradigm of digital technology-based learning places learners as the center of the learning process, as a provider of learning materials, with improved availability, self-control, and enhanced digital capabilities [7],[8]. According to this logical thinking, digital-based learning is an ideal approach because it can help students develop their language skills, accommodate their learning styles, and meet the demands of rapidly advancing digital technology [9],[10]. Since digital-based learning contributes to student's academic success, including learning English, digital literacy skills are the focus of attention of education practitioners.

Earlier studies provide strong evidence that digital literacy competencies accelerate students' acquisition of language skills, promote learning motivation, change learning habits, and personal effort in digital literacy [16-18]. Furthermore, sufficient digital literacy competencies enable the students to develop creative thinking skills, develop their English vocabulary, and improve their ability to write scientific papers [15],[19],[20].

However, scientific studies did not provide clear evidence for analyzing students' digital literacy competencies and their effects on English study habits. As a result, the aim of this study is to fill in the gap by exploring students' digital literacy competence in promoting their English study habits. A few studies have shown that digital literacy competence can impact students' English study habits, interest in learning English, independent English practice, initiative, and enthusiasm [21-23]. Students' digital literacy competencies enable them to adjust their thinking to achieve the expected learning outcomes. Students who possess qualified digital literacy competencies will be more inspired, confident and adapt their learning strategies and habits, all of which will contribute to their English proficiency [25-27].

Students are unaware that the demands of achieving digital literacy competencies impact how they learn English. Learning habits play a vital role in developing students' listening, speaking, and writing skills, as well as their vocabulary, which can lead to a rise in students' 
English output. Researchers are recommended to explore the following two research questions concerning the data and descriptions above:

a. How is the student's digital literacy competency profile?

b. Does the demand for digital literacy competencies have an impact on students' English learning habits?

Based on these two questions, this research aims to uncover empirical evidence regarding the profile of students' digital literacy competencies and improvements in their learning habits across ten study programs at Universitas Katolik Indonesia Santu Paulus Ruteng.

\section{Review of Literature}

\subsection{Concept of digital literacy competence}

Literacy is derived from the Latin littera (letter), and it refers to the ability to read and write [28],[29]. People who really can read and write are referred to as literate or literate persons. In a broader context, literacy refers to a person's capacity for processing and comprehending the meaning of literacy. The sense of literacy continues to evolve in lockstep with the changes so that literacy has been adopted in various fields of science and imparts meaning relevant to the context and the field used. This understanding then gave birth to the terminology of global awareness literacy, financial literacy, entrepreneurial literacy, citizenship literacy, health literacy, environmental literacy, and finally, resulting in the concept of digital literacy [5],[30].

Everyone must carry out literacy because it has a direct impact on their lives. Person who applies the concept of literacy regularly contributes to growing a person's vocabulary, maximizing brain performance since it is often used for reading and writing tasks, gaining new perspectives, shifting one's mindset, and sharpening one's intellectual capacity, which assists him/her in overcoming all types of underdevelopments [31],[32]. As a result, literacy comprehension is a crucial factor in daily life. With adequate and accurate literacy, an individual may actively engage in various areas of life, as it benefits the general public and the growth of his or her potential.

The advancement in digital technologies is unavoidable. This concept has an impact on humans' mindsets and work habits [13],[33]. The work pattern by relying on non-digital technology will disappear because it is ineffective and efficient in terms of time, finance, and increased language knowledge. The disruption in the era of digital technology encourages all stakeholders to display creativity, initiative and adaptive power to take advantage of the various opportunities that occur due to the development of digital technology, which continues to have a good impact on the lives of the wider community.

Digital technology is a tool that enables more efficient human work patterns. For this reason, students must possess digital literacy in order to be knowledgeable, competitive, and able to capitalize on numerous digital business opportunities. Digital literacy is the capacity of an individual to seek, comprehend, interpret, evaluate, and disseminate knowledge through digital technology developments that are often connected to an internet network [33],[34]. This literacy concept equates to the meaning of the term competence.

Students' primary objective in the twenty-first century is to demonstrate the strength of their competency levels. This expertise ensures that he/she takes advantage of all available opportunities. Numerous obstacles appear and disappear to "tease" the competency levels you already have. However, every student can survive and prosper if the skill aligned with it can 
elicit an adaptive response that is compatible with the demands of the working world. The essence of this reaction is undoubtedly the presence of competencies that continue to assist him/her in achieving brilliant accomplishments in his/her career, including digital literacy competencies [35],[36].

This digital literacy competency plays an essential role in the learning process in higher education since all fields of work require the use of digital technologies [37]. Digital literacy proficiency is also a prerequisite for administrative personnel in higher education in each unit, as all forms of reporting on the educational process are linked and standardized digitally. Therefore, all stakeholders in higher education view digital literacy competencies as the primary focus that must be managed and strengthened following the advancement and growth of digital technology.

Limitations on the spectrum of comprehension for various digital literacy competencies are different for each perspective. The three previous researchers focused their attention on five various parts [25],[38],[39]. They defined five areas of digital literacy competency that students must comprehend:(1) information literacy, which includes the ability to identify, locate, retrieve, store, organize, and analyses digital information, as well as assess its relevance and purpose;(2) communication literacy, which includes the ability to communicate in a digital environment, share resources through online tools, and connect a computer to a network. Additionally, it generates artistic works, media production, and programming in order to manage and enforce intellectual property rights and licenses; safety, which includes personal protection, data protection, digital identity protection, security measures, and efficient and sustainable use; and(5) problem-solving literacy, which includes the ability to identify digital needs and resources, make informed choices about the most appropriate digital tools for clearly defined goals or needs, solve conceptual problems using digital media, use technology creatively, and solve problems.

Competence in digital literacy is also limited by comprehending three key components: information literacy, media literacy, and information and communication technology literacy [20],[28]. These three literacy skills are required for prospective employees to increase their productivity and effectiveness in various job settings. Digital literacy competence is described in this study focuses on information literacy, media literacy, and information and communication technology literacy [41-43]. The three literacies intended are detailed in Table 1

Table 1. Digital Literacy Competence

\begin{tabular}{lll}
\hline Skill types & $\begin{array}{c}\text { Indicator } \\
\text { Information literacy }\end{array}$ & $\begin{array}{l}\text { Descriptor } \\
\text { The student can access information effectively (sources } \\
\text { of information) and efficiently (on time); evaluate the } \\
\text { information to be used carefully and wisely; use and } \\
\text { manage information appropriately and accurately to solve } \\
\text { Competence }\end{array}$ \\
instruction problems
\end{tabular}

\subsection{Digital competence and English learning habits}

Both digital literacy and media literacy and information and communication technology literacy impact improvements in student academic success. Such that internal and external factors have an impact on student academic performance. External factors, such as instructional 
procedures, classroom environment, evaluation system, and the support from the closest persons. Meanwhile, the internal factor originates with the student, such as a desire to learn, motivation, health, and study habits [44],[45]. Study habits play an essential role in determining student academic achievement, including digital literacy competencies.

A study habit is a learning activity that is usually carried out regularly and continuously in a regular daily routine to improve one's academic achievement [46],[47]. Learning habits are not inherent abilities derived from one's intrinsic factors but are deliberate and intentional patterns acquired over time. Learning habits can also be understood as a strategy owned and implemented by a student in achieving the expected learning outcomes. Achieving maximum learning outcomes encourages students to change their learning habits.

Since2018, all courses at Universitas Katolik Indonesia Santu Paulus Ruteng have been digitalized using the Modular Object-Oriented Dynamic Learning Environment (MOODLE) platform. This platform is used to facilitate online learning through a computer device. Moodle is also included in a web-based framework. Any learning activity is accommodated in various features, such as access to material, discussions, questions and answers, assignments, participation, assessment, and the like. Students must demonstrate their digital literacy abilities to taking part in this system.

This digital literacy competency has an impact on student learning habits, including English courses. Habit is away made by someone repeatedly in the same activity, and in the end, it becomes accurate and is automatic. The habit of accessing information carefully, understanding the main functions of several computer devices, using some software applications in learning contributes to the improvement of students' knowledge of English, such as vocabulary, the accuracy of pronunciation and grammar, and the accuracy of using punctuation in English writing [48],[49].

All instructions for operating various software applications are in English. Students swiftly find out the meaning of words that confuse them, and this way is not realized as a way to change English learning habits and change in reading and writing literacy. Therefore, the higher the digital literacy competence of students, the more their knowledge of English will be increased. Learning habits are closely related to the learning skills a person has. Adequate study skills possessed by a person will automatically shape their study habits, supporting maximum academic performance.

\section{Methodology}

This research used a cross-sectional survey design. It was held in March 2021 at ten study programs, Universitas Katolik Indonesia Santu Paulus Ruteng. This design's primary purpose is to determine community desires for educational resources in programs, lessons, school facilities, and school or community planning [50]. In the context of this research, this design was chosen for the improvement and development of the university's digital facilities in supporting the learning process in the ten existing study programs.

\subsection{Population and Sample}

The researcher surveyed 4142 students. A sample of 402 students was chosen using a multistage cluster random sampling technique. This sample was obtained from ten different study programs at Universitas Katolik Indonesia Santu Paulus Ruteng, as detailed in Table 2. 
Table 2. Total of Sample

\begin{tabular}{|c|c|c|c|c|}
\hline \multirow[t]{2}{*}{ No } & \multirow[t]{2}{*}{ Study Program } & \multicolumn{2}{|c|}{ Sexs } & \multirow{2}{*}{$\begin{array}{c}\text { Number of } \\
\text { Samples }\end{array}$} \\
\hline & & Female & Male & \\
\hline 1 & Theological Education & 23 & 14 & 37 \\
\hline 2 & English Language Education & 33 & 21 & 54 \\
\hline 3 & Indonesian Language Education & 24 & 20 & 44 \\
\hline 4 & Primary Teacher Education & 32 & 16 & 48 \\
\hline 5 & Mathematics Education & 25 & 17 & 42 \\
\hline 6 & Early Childhood Education Programs & 22 & 11 & 33 \\
\hline 7 & Midwifery & 31 & - & 31 \\
\hline 8 & Nursing & 30 & 12 & 42 \\
\hline 9 & Agronomy & 16 & 21 & 37 \\
\hline \multirow[t]{2}{*}{10} & Agricultural Socio-Economics & 19 & 15 & 34 \\
\hline & Amount & 255 & 147 & - \\
\hline \multicolumn{4}{|c|}{ Total number } & 402 \\
\hline
\end{tabular}

\subsection{Instrument}

The data collection instrument was a questionnaire. The literacy digital competence questionnaire referred to Trilling and Fadel's theory [42]. It examined three components of digital literacy (information, media, and ICT) using thirty items consisting of closed-ended questions with five possible responses. Participants were instructed to choose one of four choices, while the questionnaire on learning habits was adjusted from the concept proposed by Schunk, Pintrich, and Meece [51]. Before the questionnaire was distributed through Google form, three expert judgments were used to determine which items were relevant and irrelevant to the content validity.

In this analysis, a score table was used to determine students' level of digital literacy competence based on their responses to the questionnaire. After receiving a score for each answer. Additionally, the respondents' digital literacy competency levels were classified. There are four classifications: strong, medium, low, and extremely low. Table 3 below shows the range of possible scores for each group.

Table 3. Score Category Table

\begin{tabular}{ll}
\hline Score & Category \\
\hline $1,1-2,1$ & Very low \\
\hline $2,2-3,1$ & Low \\
\hline $3,2-4,1$ & Moderate \\
\hline $4,2-5,0$ & High \\
\hline
\end{tabular}

\subsection{Data Analysis}

The percentages were calculated numerically using the data from the questionnaire. This percentage was analyzed using the excel chart data series software program, and the results were then interpreted qualitatively. 


\section{Findings}

The following section describes the results regarding students' digital literacy competencies and their English learning habits. Each of these two variables' components is quantified using the excel chart data series software program. The following Tables summarise digital literacy competence and learning habits.

Table 4. The Rating of Digital Literacy Competence

\begin{tabular}{|c|c|c|}
\hline No & Item & Mean \\
\hline & Information Literacy & 3,6 \\
\hline 1 & Ability to manage personal website/homepage & 3,4 \\
\hline 2 & Web search skill & 4,2 \\
\hline 3 & Ability to create and upgrade web pages & 4,6 \\
\hline 4 & Ability to use e-mail correlates to the requirements of English language courses & 4,4 \\
\hline 5 & Ability in using the world wide web & 4,2 \\
\hline 6 & Ability to use English language learning website & 4,4 \\
\hline 7 & Ability to use Wikipedia in English courses & 2,8 \\
\hline \multirow[t]{3}{*}{8} & Ability to use online chat features, text chat and voice chat & 3,2 \\
\hline & Average & 3,9 \\
\hline & Media Literacy & \\
\hline 9 & $\begin{array}{l}\text { Ability to understand the main functions of hardware components on student's } \\
\text { computer }\end{array}$ & 3,4 \\
\hline 10 & Ability to work with MS Word, MS Excel, and MS PowerPoint programs & 3,8 \\
\hline 11 & Ability to use keyboard shortcuts on the computer & 4,2 \\
\hline 12 & Ability to change computer screen brightness and contrast & 3,4 \\
\hline 13 & $\begin{array}{l}\text { Ability to use features/programs minimize, maximize, move windows on the } \\
\text { computer screen }\end{array}$ & 3,6 \\
\hline \multirow[t]{3}{*}{14} & Ability to take, edit, and record digital photos and videos & 3,6 \\
\hline & Average & 3,6 \\
\hline & ICT Literacy & \\
\hline 15 & Ability to use graphics software in English courses & 3,4 \\
\hline 16 & $\begin{array}{l}\text { Ability to use the concordance program software application (for text analysis) } \\
\text { in English courses }\end{array}$ & 2,4 \\
\hline 17 & $\begin{array}{l}\text { Ability to use learning software applications, such as Google voice, CD-ROM, } \\
\text { DVD, and the like }\end{array}$ & 3,8 \\
\hline 18 & Ability to use the Blog application in English courses & 4,2 \\
\hline 19 & Ability to use an electronic dictionary in English courses & 4,8 \\
\hline 20 & Ability to use Skype and Moodle applications & 4,8 \\
\hline 21 & Ability to work with podcast applications in English courses & 4,2 \\
\hline 22 & Ability to work with the Dropbox application in English courses & 3,8 \\
\hline 23 & Ability to work with the YouTube application in English course & 3,8 \\
\hline 24 & Ability to use Google classroom application in English course & 3,2 \\
\hline \multirow[t]{2}{*}{25} & $\begin{array}{l}\text { Ability to work with Edmodo, Canvas, Zoom, Busuu, and the like in English } \\
\text { course }\end{array}$ & 3,2 \\
\hline & Average & 3,78 \\
\hline
\end{tabular}


The statement items in Table 4 cover three indicators of digital literacy competence, namely information literacy (items 1-8), media literacy (items 9-14), and ICT literacy (15-25). Based on the data analysis, students' digital literacy level of the Universitas Katolik Indonesia Santu Paulus Ruteng on information literacy is categorized at a moderate level with an average total score of 3.9. The media literacy level score is categorized at the medium level with an average score of 3.5. Likewise, the ICT literacy level score is categorized at a moderate level with an average score of 3.8. Table 5 explains the three indicators of digital literacy competence mentioned previously.

Table 5. Digital Literacy Competence

\begin{tabular}{llcll}
\hline Competence types & \multicolumn{1}{c}{ Indicator } & N & Mean & Category \\
& Information Literacy & 402 & 3,9 & Moderate \\
Digital Literacy & Media Literacy & 402 & 3,6 & Moderate \\
& ICT Literacy & 402 & 3,78 & Moderate \\
Final average & & & 3,76 & Moderate \\
\hline
\end{tabular}

The data in Table 5 concludes that the digital literacy competency level of 402 students, Universitas Katolik Indonesia Santu Paulur Ruteng is in the medium category $(3,7)$. The demands of students' digital literacy competencies also impact changes in student learning habits in English courses. Numerous factors serve as measures of learning habits, including study habits, learning motivation, learning environment, frequency of study lessons, summarizing, consistently doing exercises, having a fixed study schedule, being consistent with study time allocation, setting priorities on each study, and self-evaluation [52]. Responses "yes / positive" are given a score of 1 (one), and responses "no / negative" are given a score of o (zero). Furthermore, the mean percentage of all questions for the six indicators can be explained in Diagram 1 below.

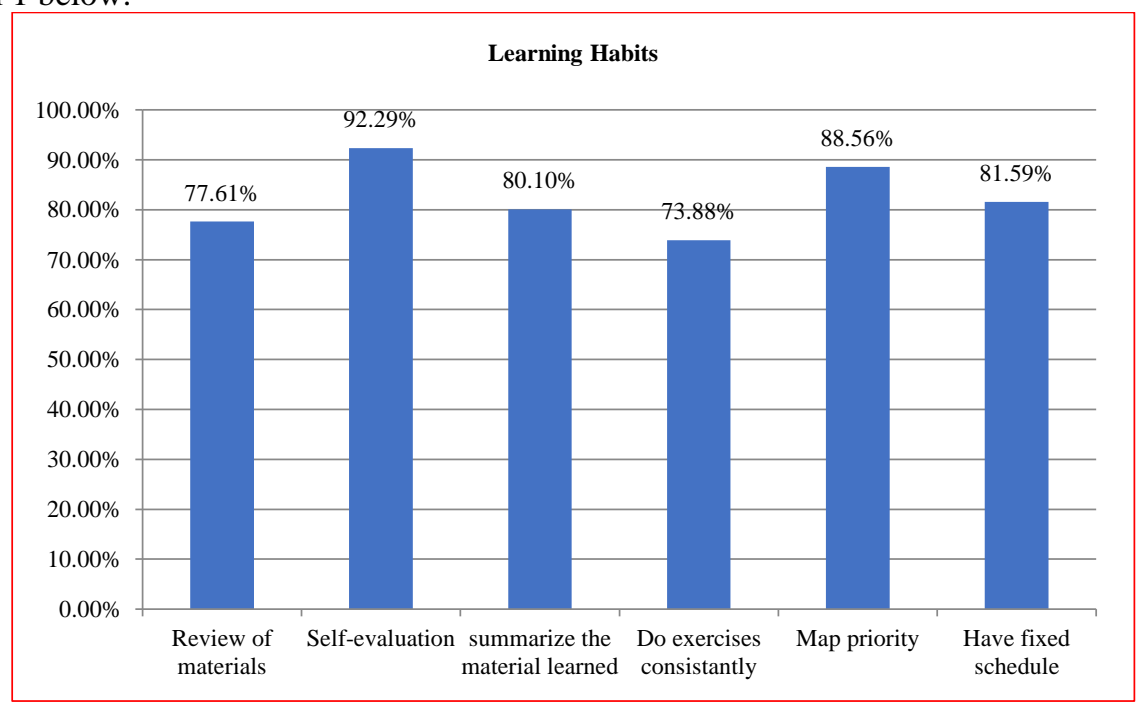

Fig 1. Study habits 


\section{Discussion}

Students have a medium level of digital literacy competency (Table 5). The percentage of English learning habits is either relatively high or entirely good. These findings confirm that the demands for digital literacy competencies impact students' English proficiency and their learning habits. That is the demands of digital literacy (information literacy, media literacy, and ICT literacy) as a path and ability for students to continuously explore a depth of English knowledge [21],[53].

English proficiency is essential for students to achieve digital literacy competencies or meet the demands of digital literacy. English proficiency is often acquired unconsciously by students [23]. As an illustration, consider information literacy. This literacy allows students to access information effectively (sources of information) and efficiently (on time), which can only be accomplished if students have an adequate command of the English language, as all instructions in digital media are written in the language. On the other hand, media literacy allows students to consider the primary functions of the hardware components of the electronic media they have. Those students need an understanding of English vocabulary in order to operate their computer media. Therefore, it is inevitable if digital literacy is a source of knowledge for students [54].

ICT literacy, which is understood as a student's ability to use various digital applications, also encourages the improvement of students' knowledge of English, such as listening skills, speaking skills, writing skills, grammar, and vocabulary [49],[54],[55]. These researchers provide concrete examples related to ICT literacy in the context of using a speech visualization application that acts as a speech analyzer in measuring students' English pronunciation accuracy [56]. Students may use this application to assess their grammar, listening, and speaking skills, which students often ignore.

Digital literacy also impacts changing student study habits, reading literacy, writing literacy, learning independence, and self-regulation [17],[57]. Various challenges in achieving an adequate level of digital literacy competence can be helped by implementing a consistent culture of reading and writing literacy. With the demands of ideal digital literacy competencies, students independently make various breakthroughs to fulfil them. Students may explore digital information, examine, assess, build, or establish their conclusions through their initiative and curiosity. This conclusion becomes something to be proud of as it is enjoyable, meaningful, and self-contained. Therefore, independent learning is an essential variable in meeting the demands of digital literacy competencies [24],[58],[59].

Improvements in students' learning habits are strongly intertwined with the requirements for digital literacy competencies. Learning habits are described as behaviors performed on a regular, consistent, and continuous basis [60]. Student learning tasks such as creating a review while studying, consistently completing assignments/exercises, upholding a study schedule, being consistent with the allocation of study time, setting goals for each study, and performing self-evaluation of their learning progress demonstrate an understanding of the learning as mentioned earlier habits [44],[61].

By implementing these six indicators of learning habits, students acquire knowledge of English and develop the ability to analyses, draw accurate conclusions from the language's topics, and promote positive learning and language attitude [62],[63]. Students who have a learning habit during the lesson period will appear differently from those who do not. This concept is evident in listening and accuracy in using vocabulary when speaking and writing exercises in paragraph form. 


\section{Conclusion}

Competence in digital literacy and English are two reciprocal variables. Competence in digital literacy motivates students to improve their English learning habits. On the other hand, the ability to communicate effectively in English assists students in developing their proficiency or competence in digital literacy. Three primary indicators of digital literacy are knowledge literacy, media literacy, and ICT literacy. According to data analysis results, each of these indicators is at a moderate level.

So, the digital literacy competency level of the 402 students at Universitas Katolik Indonesia Santu Paulus Ruteng can be classified as medium. This demand for digital literacy competencies has an impact on changing student learning habits in English courses which are in the high category. Six indicators of learning habits indicate this category: making a summary while studying, consistently doing exercises, having a sedentary learning schedule, consistent with the allocation of study time, setting priorities for each study, and self-evaluation.

\section{Acknowledgements}

We would like to express our gratitude to the Rector of Universitas Katolik Indonesia Santu Paulus Ruteng for endorsing and facilitating this study.

\section{References}

[1] C. K. Gomathy, "A study on the effect of awareness and education on digital literacy,” Int. J. Sci. Res. Rev., vol. 7, no. 3, pp. 51-57, 2018.

[2] A. Suherman, T. Supriyadi, and I. Safari, "Promoting digital literacy skills: An action research to people of Kampung Literasi,” Univers. J. Educ. Res., vol. 8, no. 4, pp. 1372-1386, 2020.

[3] J. Usman, "Pengelolaan infrastruktur teknologi informasi dan komunikasi dalam mendukung kinerja layanan pendidikan di Sekolah Tinggi Agama Islam Negeri (STAIN) Pamekasan,” J. Anal. Sist. Pendidik. Tinggi, vol. 1, no. 2, pp. 79-92, 2017.

[4] H. Elmunsyah, "A Study of ICT infrastructure and access to educational information in the outskirts of Malang.," Acta Didact. Napocensia, vol. 5, no. 2, pp. 41-48, 2012.

[5] S. Menggo, "Pembelajaran abad 21," in Seminar Nasional Linguistik dan Linguistik Terapan, 2020, pp. 1-20.

[6] S. Sukmawati and N. Nensia, "The role of Google classroom in ELT," Int. J. Educ. Vocat. Stud., vol. 1, no. 2, pp. 142-145, 2019.

[7] I. M. Amin, R. Mansur, and M. Sulistiono, "Peran literasi digital dalam meningkatkan pembelajaran pendidikan agama islam di kelas XI IIS 01 SMAI AL Maarif Singosari Malang," Vicratina J. Pendidik. Islam, vol. 6, no. 1, pp. 58-67, 2020.

[8] T. Andriani, Sistem pembelajaran berbasis teknologi informasi dan komunikasi, vol. 12, no. 1. 2015, pp. 128-150.

[9] Permendikbud No 65, peraturan menteri pendidikan dan kebudayaan tentang standar proses pendidikan dasar dan menengah. 2013, pp. 1-13.

[10] N. Suryani, "Utilisation of digital media to improve the quality and attractiveness of the teaching of history," in the 2nd International Conference on Teacher Training and Education Sebelas Maret University, 2016, vol. 2, no. 1, pp. 131-144.

[11] R. Miño-puigcercós and J. M. Sancho-gil, "Learning by using digital media in and out of school," Int. J. Media, Technol. Lifelong Learn., vol. 11, no. 1, pp. 1-17, 2015.

[12] L. A. Anggrasari, "Penerapan e-learning untuk meningkatkan kemampuan literasi digital di era new normal,” Prem. Educ. J. Pendidik. Dasar dan Pembelajaran, vol. 10, no. 2, pp. 248-256, 2020. 
[13] A. D. Yazon, K. Ang-manaig, C. A. C. Buama, and J. F. B. Tesoro, "Digital literacy, digital competence and research productivity of educators," Univers. J. Educ. Res., vol. 7, no. 8, pp. 1734 1743, 2019.

[14] H. Cai, "E-learning and English teaching," Procedia-Social Behav. Sci., vol. 2, pp. 841-846, 2012.

[15] S. Kim, "Developing autonomous learning for oral proficiency using digital storytelling," Lang. Learn. Technol., vol. 18, no. 2, pp. 20-35, 2014.

[16] F. Giovanni and N. Komariah, "Hubungan antara literasi digital dengan prestasi belajar siswa SMA Negeri 6 Kota Bogor,” Libr. J. Perpust., vol. 7, no. 1, pp. 147-162, 2020.

[17] S. M. Jannah, "Analysis level of digital literacy of digital natives: How the impact on their selfregulated learning?" Ekspektra J. Bisnis dan Manaj., vol. 3, no. 2, pp. 173-185, 2019.

[18] A. M. Al Kandari and M. M. Al Qattan, "E-task-based learning approach to enhancing 21 st-century learning outcomes,” Int. J. Instr., vol. 13, no. 1, pp. 551-566, 2020.

[19] O. Mantiri, G. K. Hibbert, and J. Jacobs, "Digital literacy in ESL classroom," Univers. J. Educ. Res., vol. 7, no. 5, pp. 1301-1305, 2019.

[20] M. Maryatun, "Efektivitas kegiatan literasi digital dalam meningkatkan kemampuan penulisan karya ilmiah bagi mahasiswa," Fikris J. Ilmu Perpust. dan Inf., vol. 15, no. 2, pp. 145-166, 2020.

[21] J. Jumino, "Application of information literacy based on English ability: Case study of the information and library science S-1 study program students, academic year 2013,” Anuva J. Kaji. Budaya, Perpustakaan, dan Inf., vol. 2, no. 1, pp. 11-17, 2019.

[22] B. Murtafi and N. H. P. S. Putro, "Digital literacy in the English curriculum: Models of learning activities," Acta Inform. Malaysia, vol. 3, no. 2, pp. 11-14, 2019.

[23] C. Yuan, L. Wang, and J. Eagle, "Empowering English language learners through digital literacies: Research, complexities, and implications," Media Commun., vol. 7, no. 2, pp. 128-136, 2019.

[24] L. D. A. Soto and Y. A. G. Gutierrez, "Digital literacy and basic self-regulation habits in early childhood learning of English as a foreign language," Folios, no. 49, pp. 177-196, 2018.

[25] H. S. Harjono, "Literasi digital: Prospek dan implikasinya dalam pembelajaran bahasa," Pena J. Pendidik. Bhs. dan Sastra, vol. 8, no. 1, pp. 1-7, 2018.

[26] N. Ozdamar-Keskin, F. Z. Ozata, and K. Banar, "Examining digital literacy competences and learning habits of open and distance learners," Contemp. Educ. Technol., vol. 6, no. 1, pp. 74-90, 2015.

[27] K. K. Frankel, B. L. C. Becker, M. W. Rowe, and P. D. Pearson, "From 'what is reading?' to what is literacy?" J. Educ., vol. 196, no. 3, pp. 7-17, 2016.

[28] C. M. A. Goulart, "The concept of literacy under analysis: Towards a discursive perspective of alphabetisation," Bakhtiniana, vol. 9, no. 2, pp. 40-56, 2014.

[29] A. Afandi, T. Junanto, and R. Afriani, "Implementasi digital-age literacy dalam pendidikan abad 21 di Indonesia," in Peningkatan Kualitas Pembelajaran Sains dan Kompetensi Guru melalui Penelitian \& Pengembangan dalam Menghadapi Tantangan Abad-21, 2016, pp. 113-119.

[30] E. Sumiati and W. Wijonarko, "Manfaat literasi digital bagi masyarakat dan sektor pendidikan pada saat pandemi Covid-19," Bul. Perpust. Univ. Islam Indones., vol. 3, no. 2, pp. 65-80, 2020.

[31] R. Rintaningrum, "Literacy: Its importance and changes in the concept and definition," TEFLIN J., vol. 20, no. 1, pp. 1-7, 2009.

[32] M. Spante, S. S. Hashemi, M. Lundin, and A. Algers, "Digital competence and digital literacy in higher education research: Systematic review of concept use," Cogent Educ., vol. 5, no. 1, pp. 121, 2018.

[33] C. Lankshear and M. Knobel, "Digital literacy and digital literacies: Policy, pedagogy and research consideration for education,” Nord. J. Digit. Lit., pp. 8-20, 2016.

[34] J. V Allen, "Developing digital literacy skills through guided reading," Florida Read. J., vol. 51, no. 1 , pp. 16-20, 2016.

[35] S. Menggo, "Optimalisasi pemanfaatan teknologi audio-visual dalam kompetensi komunikasi bahasa Inggris," in Transformasi Pendidikan Abad 21, 2017, pp. 88-95.

[36] P. Ayyildiz, A. Yilmaz, and H. S. Baltaci, "Exploring digital literacy levels and technology integration competence of Turkish academics," Int. J. Educ. Methodol., vol. 7, no. 1, pp. 15-31, 2021. 
[37] B. S. K. Chan, D. Churchill, and T. K. F. Chiu, "Digital literacy learning in higher education through digital storytelling approach,” J. Int. Educ. Res., vol. 13, no. 1, pp. 1-16, 2017.

[38] F. Pettersson, "On the issues of digital competence in educational contexts - a review of literature," Educ. Inf. Technol., vol. 23, pp. 1005-1021, 2018.

[39] D. Radovanović et al., "Digital literacy key performance indicators for sustainable development," Soc. Incl. J., vol. 8, no. 2, pp. 151-167, 2020.

[40] Y. Anggeraini, A. Faridi, J. Mujiyanto, and D. A. L. Bharati, "Literasi digital: Dampak dan tantangan dalam pembelajaran bahasa," in Seminar Nasional Pascasarjana UNNES, 2019, pp. 386389.

[41] S. Menggo, I. M. Suastra, M. Budiarsa, and N. N. Padmadewi, "Needs analysis of academicEnglish speaking material in promoting 21 st century skills," Int. J. Instr., vol. 12, no. 2, pp. 739 754, 2019.

[42] B. Trilling and C. Fadel, 21st-century skills: Learning for life in our times. San Francisco: JosseyBass, 2009.

[43] W. Techataweewan and U. Prasertsin, "Development of digital literacy indicators for Thai undergraduate students using mixed method research," Kasetsart J. Soc. Sci., vol. 39, no. 2, pp. 215-221, 2020.

[44] A. Amri, A. Aridah, and W. ParamaIswari, "Study habits and English learning achievement of vocational high school students in Samarinda," Adv. Soc. Sci. Educ. Humanit. Res., vol. 432, pp. 47-51, 2020.

[45] S. Menggo, I. N. Suparwa, and I. G. Astawa, "Hindering factors in the achievement of English communicative competence in tourism academy students," Aksara, vol. 31, no. 1, pp. 137-152, 2019.

[46] M. Hidayat, "Pengaruh kebiasaan belajar, lingkungan belajar, dan dukungan orang tua terhadap prestasi belajar mata pelajaran ekonomi pada siswa kelas IX IPS di Man Bangkalan,” J. Ekon. Pendidik. dan Kewirausahaan, vol. 3, no. 1, pp. 103-114, 2015.

[47] M. Urh and E. Jereb, "Learning habits in higher education," Procedia - Soc. Behav. Sci., vol. 116, no. February 2013, pp. 350-355, 2014.

[48] M. Hajebi, S. Taher, F. Fahandezh, and H. Salari, "The role of web-based language teaching on vocabulary retention of adult pre-intermediate EFL learners," J. Lang. Teach. Res., vol. 9, no. 2, pp. 372-378, 2018.

[49] H. Alkan and N. T. Bümen, "An action research on developing English speaking skills through asynchronous online learning,” Int. J. Curric. Instr., vol. 12, no. 2, pp. 127-148, 2020.

[50] W. Creswell, J, Educational research: Planning, conducting, and evaluating quantitative and qualitative research, Third. New Jersey: Pearson Education, Inc., 2008.

[51] H. D. Schunk, R. P. Pintrich, and L. J. Meece, Motivation in Education: Theory, Research, and Applications, Third Ed. New Jersey: Pearson Education, Inc., 2008.

[52] B. Bungin, Metode penelitian kuanlitatif: Komunikasi, ekonomi, kebijakan publik, dan ilmu sosial lainnya, 2nd ed. Jakarta: Prenada Media Group, 2005.

[53] M. Benali, M. Kaddouri, and T. Azzimani, "Digital competence of Moroccan teachers of English," Int. J. Educ. Dev. Using Inf. Commun. Technol., vol. 14, no. 2, pp. 99-120, 2018.

[54] E. F. Rusydiyah, E. Purwati, and A. Prabowo, "How to use digital literacy as a learning resource for teacher candidates in Indonesia," Cakrawala Pendidik., vol. 39, no. 2, pp. 305-318, 2020.

[55] M. R. Ahmadi, "The use of technology in English learning: A literature review," Int. J. Res. English Educ., vol. 3, no. 2, pp. 115-125, 2018.

[56] X. Liu, D. Wu, Y. Ye, M. Xu, and J. Jiao, "Improving accuracy in imitating and reading aloud via speech visualisation technology," International J. Emerg. Technol. Learn., vol. 15, no. 8, pp. 144$160,2020$.

[57] M. F. Akbar and F. D. Anggraeni, "Teknologi dalam pendidikan : Literasi digital dan self-directed learning pada mahasiswa skripsi," Indig. J. Ilm. Psikol., vol. 2, no. 1, pp. 28-38, 2017.

[58] E. Üstünlüoğlu, "Autonomy in language learning: Do students take responsibility for their learning?” J. Theory Pract. Educ., vol. 5, no. 2, pp. 148-169, 2009. 
[59] H. Reinders, "Towards a classroom pedagogy for learner autonomy: A framework ofindependent language learning skills,” Aust. J. Teach. Educ., vol. 35, no. 5, pp. 40-55, 2010.

[60] I. K. Alrefaai, S. D. A. Rab, and M. S. Islam, "The general study habits of major EFL students in King Khalid University and their relationships with GPA, Ggender and certain social factors," Umm Al-Qurma Univ. J. Lang. Lit., vol. No 10, pp. 11-63, 2013.

[61] M. A. Cerna and K. Pavliushchenko, "Influence of study habits on academic performance of international college students in Shanghai," High. Educ. Stud., vol. 5, no. 4, pp. 42-55, 2015.

[62] S. Menggo and I. M. Suastra, "Language use and language attitudes of Sumbawanese speakers in Bali," Regist. J., vol. 13, no. 2, pp. 333-350, 2020.

[63] S. Menggo, "English learning motivation and speaking ability," J. Psychol. Instr., vol. 2, no. 2, pp. 64-69, 2018. 